\title{
THE MOST IMPORTANT ANGIOGENIC GROWTH FACTORS INFLUENCING THE DEVELOPMENT AND FUNCTION OF BLOOD VESSELS - IN THE CONTEXT OF CORONARY ARTERY BYPASS GRAFTING (CABG)
}

\author{
Karolina STERZYNSKA ${ }^{1,2}$, Patrycja SUJKA-KORDOWSKA ${ }^{1,2}$, Wojciech \\ WITKIEWICZ ${ }^{2}$ \\ ${ }^{1}$ Department of Histology and Embryology, University of Medical Sciences, \\ Poznan, Poland \\ ${ }^{2}$ Regional Specialized Hospital in Wroclaw, Research and Development Center, \\ Wroclaw, Poland
}

DOI: $10.2478 / \mathrm{v} 10052-011-0004-3$

\begin{abstract}
Summary: Currently available approaches for treating patients with ischemic heart disease include medical therapy or coronary revascularization by surgical procedures, like coronary artery bypass grafting (CABG). Bypass grafting often provides dramatic relief from the symptoms of myocardial ischemia. However, a significant number of patients are not candidates for these kind of treatment or achieve incomplete revascularization. Hence, an alternative treatment strategy such as therapeutic angiogenesis has emerged as a new method for patients with inoperable coronary artery disease. Recently it has been demonstrated that angiogenic growth factors, like vascular endothelial growth factor or fibroblast growth factor, can improve myocardial perfusion and function.
\end{abstract}

Key words: coronary artery disease (CAD), coronary artery bypass grafting (CABG), angiogenic growth factors

\section{INTRODUCTION}

The mechanisms of vasculogenesis, angiogenesis and arteriogensis play a major role in the myocardium revascularization process. Although, pharmacological and surgical (Coronary Artery Bypass Grafting - CABG, Percutaneous Transluminal Coronary Angioplasty - PTCA) therapies are available in the treatment of coronary artery disease they often are not effective and the 
mechanisms of revascularization remain still unclear. Therefore, a new strategies with use of many different factors influencing the blood vessels formation have been applied in the treatment of coronary artery disease (CAD).

Angiogenic factors fulfill a major role in the formation and function of blood vessels during vascular healing in response to mechanical disruption induced by surgical procedures (e.g. CABG).

This article is a review of the current knowledge about an important factors taking part in blood vessels development. The most important are as follows: Vascular Endothelial Growth Factor (VEGF), Fibroblast Growth Factor (FGF), Platelet Derived Growth Factor (PDGF), Angiopoietins (Ang), Transforming Growth Factor $\beta$ (TGF- $\beta$ ).

\section{CORONARY ARTERY BYPASS GRAFT (CABG)}

Coronary artery disease (CAD) is the leading cause of mortality in developed countries. The disease develops because of hardening of the arteries (atherosclerosis) that supply blood to the heart muscle. The atherosclerotic plaque builds up in the wall of the arteries that supply the heart. The atherosclerotic process causes significant narrowing in one or more coronary arteries. The treatment of CAD is designed to relieve the symptoms of myocardial ischemia and prevent myocardial infarction or sudden death. In many instances the only useful treatment is revascularization by, among others, coronary artery bypass graft surgery (CABG) [69]. CABG that uses another artery or vein reestablishes sufficient blood flow to deliver oxygen and nutrients to the heart muscle. Since the 1960s CABG has been a mainstay in CAD treatment and reduced the death rate from CAD. However, the long term clinical outcome after revascularization depends on the patency of bypass graft. The most popular venous grafts have demonstrated a tendency to develop partial or complete occlusions with time. In turn, arterial grafts have shown relative resistance to plaque formation and obstruction but are more limited in their availability and ease of procurement compared with venous conduits [21].

Patients, who undergo complete revascularization have improved 5-year survival and angina-free survival time [40]. However, the success of CABG surgery may be limited by inability to provide complete revascularization [34, 47]. This state can be evoked by diffuse disease, calcifications or small size of artery, which is needed to be transplanted. In these patients the experience of residual myocardial ischemia continues despite intensive medical therapy [61]. Therefore, an adjunctive treatment strategy is warranted in patients undergoing CABG if complete revascularization is not possible. The additional blood flow to incompletely revascularized areas can be provided by therapeutic angiogenesis, which could serve as a biological bypass of the atherosclerotic vessel [59, 38, 54]. 
Exogenously administrated angiogenic growth factors can promote new vessels formation. They may be administrated either directly or through gene-based approaches, also simultaneously with surgical procedure [33].

\section{ANGIOGENIC FACTORS}

\section{Vascular Endothelial Growth Factor (VEGF)}

Vascular endothelial growth factor represents a family of glycoproteins that plays a critical role in development of blood vessels during embryogenesis, in development of lymphatic vessels and in formation of new blood vessels from preexisting ones. VEGF is heparin-binding glycoprotein that is a specific mitogen for vascular endothelial cells. The VEGF family consists of: VEGF-A, VEGF-B, VEGF-C, VEGF-D, orf-virus VEGF-E and snake venom VEGF-F [44, 71]. All those molecules bind to three different VEGF receptors that are tyrosine kinases: VEGFR-1 (Flt-1), VEGFR-2 (Flk-1/KDR), VEGFR-3 (Flt-4). All VEGF receptors are highly expressed during embryogenesis. In adults, VEGFR-1 and VEGFR-2 are mainly expressed in endothelial cells of blood vessels whereas VEGFR-3 only in lymphatic system [68]. The highest affinity for VEGF demonstrates VEGFR-1 but the effects of VEGF on cellular processes are mainly mediated via VEGFR-2. The activation of VEGFR-2 in the vascular endothelium has an effect on cell proliferation, migration, permeability and survival processes and have results in vasculogenesis and angiogenesis [32].

VEGF-A and its receptor VEGF-R2 represent a major factors of signaling system in the early stages of blood vessels growth, both in developing embryos and in adult angiogenesis [72]. VEGF-A is produced by different cells including vascular smooth muscle cells, macrophages and tumor cells and an important regulator of its expression is oxygen tension [8, 62]. VEGF-A is involved in many steps of angiogenesis. It promotes vasodilatation by the induction of NO resulting in increased blood flow to tissues. VEGF-A increases also the permeability of endothelial cells. An increase in microvascular permeability by enhancing the transport via fenestrations, transcellular gaps and vesiculo-vacuolar organelles is a crucial step in angiogenesis associated with wounds and tumors [35, 18, 4]. In addition, VEGF-A induces the expression of plasminogen-activators (PA) and metalloproteinases, the factors that promote a degradation of environment and remodeling of the perivascular matrix. This facilitates a migration and sprouting of endothelial cells towards a concentration gradient of VEGF and other growth factors [50, 17]. Furthermore, VEGF-A enhances the proliferation of primary endothelial cells, prevents endothelial cells from apoptosis, promotes expression of cellular adhesion molecules (CAMs) in endothelial cells, and have a regulatory effects on certain blood cells (e.g. monocytes) [73, 45, 13]. 
The other type of VEGF is VEGF-B that is mainly expressed in heart and skeletal muscle and is co-expressed with VEGF-A. VEGF-B forms dimers bound to membrane or to extracellular matrix and is released in soluble form by heparin or high salt treatment [48]. This factor participates in the regulation of fully developed blood vessels and is not necessary for embryonic development because other members of VEGF family can adopt its function [72].

VEGF-C acts through the VEGFR-2 and VEGFR-3 receptors but demonstrates higher affinity to the latter one. Therefore, it regulates the growth and maintenance of lymphatic vessels [37]. Similarly to VEGF-C, VEGF-D also activates both VEGFR-2 and VEGFR-3, and is mainly expressed in the lung during embryogenesis hence it plays a role in lung development [19]. VEGF-E is a parapoxvirus orf virus protein whereas VEGF-E is of snake venom origin but both factors can stimulate angiogenesis via VEGFR-2 activation $[44,70]$.

\section{VEGF-CABG}

Metais et al. examined the effects of coronary artery disease (CAD) on expression of VEGF and its receptors in the human heart. They suggest that VEGF is a potent coronary vasodilator in the human coronary microcirculation and that mediates its effects by the release of endothelium-derived NO. Additionally, CAD is associated with a reduction in vascular response to this angiogenic growth factor [46].

Hypoxia and myocardial ischemia, occurring after coronary artery bypass graft surgery, are major agents that cause rise in the circulating level of vascular endothelial growth factor [10]. VEGF secretion may also be a response to paracrine factors such transforming growth factor $\beta$ (TGF- $\beta$ ) or fibroblast growth factor -2 (FGF-2). Both factors are produced by the heart in response to myocardial ischemia and can stimulate VEGF production [28, 60].

VEGF plasma concentration can also change during the coronary artery bypass surgery. Denizot et al. observed that levels of VEGF were stable during the surgery and increased significantly within 24 post-operative hours. After CABG surgery VEGF can stimulate proliferation of endothelial cells and promotes neoangiogenesis. It is likely related to endothelialization of implanted graft conduits following surgery [16].

\section{Fibroblast Growth Factor (FGF)}

A family of fibroblast growth factors consists of twenty distinct FGFs, numbered consecutively from 1 to 20 , and four different receptors that are tyrosine kinases (FGFR). The most important in stimulating of angiogenesis and the first to be discovered are FGF-1 (acid FGF - aFGF) and FGF-2 (basic FGF - bFGF) [53]. Both factors are secreted by a wide range of different cell types and function as mitogens for endothelial cells, fibroblasts, macrophages, smooth muscle cells [63]. In particular, FGF-2 is the factor that influences the expression of VEGF and other 
molecules, hence directly takes a part in angiogenesis. FGF-2 is a heparin-binding protein present in the normal myocardium and the hypoxia or hemodynamic stress, are the agents responsible for increase of FGF-2 expression [11, 58]. Elevated levels are found in pericardial fluid of patients with unstable angina and in infarcted myocardial tissues [23, 7]. According to Claffey et al., FGF-2 promotes a proliferation of stromal cells and additionally can activate VEGF expression in many of these stromal cells. However, the pattern of VEGF expression is distinct here from endothelial cells one. In such microenvironment the formation of new blood vessels will be promoted by the combination of both FGF-2 and VEGF functions and is critical especially in context of tumorigenesis. The other functions of FGF-2 are similar to effects of VEGF and involve as follows: regulation of cell proliferation and integrin expression, activation of metalloproteinases, influence on cell permeability and cell migration, and formation of vessels lumen [12].

\section{FGF-CABG}

Levels of angiogenic growth factors can change during cardiac surgery, e.g. coronary artery bypass graft surgery. Possible changes in concentration levels of those factors can be measured in plasma before, during and after surgery. Denizot et al. determined the plasma levels of FGF-2 in patients during and after CABG surgery. They observed that concentration of FGF-2 during surgery was increased and returned to preoperative values in six hours after operation [16]. The results are consistent with results of other group of researchers and suggest that heart can be a potential source of FGF-2 [1]. They also agree with other researchers that exogenous administration of FGF-2 can be beneficial in patients undergoing coronary bypass surgery [61].

Laham et al. conducted study of FGF-2 implanted in ischemic myocardial territories in patients undergoing CABG. They observed lack of angina in most of patients and suggest a beneficial effect of such treatment. In conclusion, they demonstrated that FGF-2 application to patients undergoing CABG is a safety and feasible method of revascularization especially these areas of viable and ischemic myocardium that cannot be revascularized in surgical way [38].

\section{Platelet Derived Growth Factor (PDGF)}

The platelet derived growth factors are a family of growth factors that with regard to polypeptide structure are similar to VEGFs and placental growth factor. PDGFs are made of four different polypeptide chains (A, B, C and D) that are able to homodimerize and heterodimerize to form five different ligands (PDGF-AA, PDGF-AB, PDGF-BB, PDGF-CC and PDGF-DD) [30, 41, 39]. The ligands act through three PDGF receptors (PDGF- $\alpha \alpha$, PDGF- $\alpha \beta$ and PDGF- $\beta \beta$ ) that are tyrosine kinases receptors [2]. The major storage place of PDGF in the organism are granules of platelets but factor is synthesized also by different cell types e.g. fibroblasts, pericytes, keratinocytes, vascular smooth muscle cells, neurons, 
glomerular mesangial cells [2]. Endothelial cells express only PDGF- $\beta$ receptors that can be stimulated only by PDGF-BB form and induces tube formation, sprouting and proliferation [6]. Additionally, PDGF-BB act as a mitogen for smooth muscle cells and pericytes and stimulates VEGF and VEGFR-2 expression in cardiac endothelial cells [6]. Stimulation of proliferation of smooth muscle cells affect the thickening of the intima in blood vessels and also cause the chronic fibrotic process, that is a reason of atherosclerosis [30].

Under certain conditions PDGF can exert contrary biological effects. For instance, can stimulate chemotaxis of certain cell types by acting through the PDGF- $\beta$ receptor and simultaneously can inhibit chemotaxis of fibroblasts and smooth muscle cells by acting through PDGF- $\alpha$ receptor [36]. Except of mitogenic effects of PDGF on different cells, platelet-derived growth factor additionally can induce cell migration, actin reorganization, and prevent cell death by apoptosis [2]. During the embryonal development PDGF takes part in development of vascular mural cells that are vascular smooth muscle cells and pericytes. These cells function as a source of anti-proliferative factors that stabilize the neovascular endothelial sprouts. The interruption of PDGF-induced signaling causes development of defective blood vessels and is lethal for neonates [42].

Alterations in PDGF expression occur in many healing processes that involve reepithelialization and angiogenesis. For example during inflammation in the wounded area overexpression of PDGF receptor is increased. Overactivity of PDGF is associated also with atherosclerosis that is considered as an excessive inflammatory fibro-proliferative process occurring in blood vessels [55]. As a result of this process PDGF is secreted by activated macrophages, smooth muscle cells, endothelial cells, and platelets during the formation of atherosclerotic lesions [56].

Rutherford et al. suggest that PDGF-B together with bFGF are involved in the process of arterial restenosis after percutaneous transluminal angioplasty. They also investigated that treatment with antibodies against PDGF-B and bFGF simultaneously result in substantial reduction in intimal thickness and intimalmedial area ratio [57].

\section{Angiopoietins (Ang)}

The family of angiopoietins comprises a growth factors (Ang1, Ang2, Ang3, Ang4) and their receptors (Tie1, Tie2), which act specifically on endothelial cells and are essential for blood vessel formation. Ang1 and Ang2 are characterized very well since they play a major role in angiogenesis and act through the Tie2 receptor. Ang3 and Ang4 are less well defined, however Ang3 is of mouse origin and is widely expressed in different tissues whereas Ang4 is human angiopoietin and can be found only in the lung. Nevertheless, both - Ang3 and Ang4 -bind to the Tie 2 receptor [67]. 
Results of many studies demonstrate that VEGFs and angiopoietins collaborate not only during development of the blood vessels but also during lymphatic vessels formation. VEGFs are responsible for proliferation, initiation and blood vessels sprouting whereas angiopoietins are involved in secondary stages of vessels growth like remodeling, maturation and formation of complex networks $[24,66]$.

Angiopoietin 1 is expressed by the myocardium in early development and by perivascular cells later in development and in adult tissue. However, the factor that can be also secreted by vascular smooth muscle cells is not able to induce proliferation or tube formation in endothelial cells in vitro but can promote sprouting of endothelial cells [14]. The fact that angiopoietin 1 interacts with Tie2 receptor on endothelial cells suggests that this member of angiopoietins family is essential for maturation and stabilization of the developing blood vessels and for physiological blood vessels remodeling.

Under physiological conditions angiopoietin 2 is produced at low levels exclusively by endothelial cells where it is stored in Weibel-Palade bodies. Following cytokine activation of the endothelium or in the hypoxia conditions Ang2 is up-regulated and rapidly released [20, 52]. It is also highly expressed at sites of vascular remodeling in adults, such as in the ovary and highly vascularized tumors. The expression of Ang2 is changed during vessel growth and regression process, suggesting that it plays an important role in vessel remodeling [31]. Ang2 act as a complex regulator that simultaneously plays a role in blood vessel sprouting and regression. It is rapidly expressed in the presence of VEGF and mediates an increase in the capillary diameter, induces migration and proliferation of endothelial cells and promotes angiogenic sprouting. On the other hand, induction of Ang2 in the absence of VEGF causes apoptosis of endothelial cells and correlates with vascular regression [43].

\section{Transforming Growth Factor $\beta$ (TGF- $\beta$ )}

Among the factors regulating VEGF levels the most potent stimulator for its production is transforming growth factor $\beta$ (TGF- $\beta$ ). TGF- $\beta$ is a multifunctional cytokine that stimulates cell proliferation and angiogenesis in areas of inflammation and can alter the morphology and function of mesothelial cells and increase their permeability [51,64]. Additionally, it is a regulator of extracellular matrix (ECM) synthesis, cell cycle progression, apoptosis, differentiation and migration. It plays a significant role not only during vascular development but also in arteriogenesis, neointima proliferation and vessel remodeling [25].

The first member of the TGF- $\beta$ family to be discovered and best-studied is TGF- $\beta 1$. It is present at high levels in the healthy blood vessel wall. Two other isoforms - TGF- $\beta 2$ and TGF- $\beta 3$ - are present at low levels or are absent [27]. Alhough three isoforms of TGF- $\beta$ were discoverd, in humans TGF- $\beta 1$ seems to be the crucial one and usually is named just as TGF- $\beta$. 
TGF- $\beta$ is produced by vascular endothelial cells, vascular smooth muscle cells, pericytes and inflammatory cells. It also stimulates thickening of intima as well in arteries as in veins [22].

Like angiopoietin 2, TGF- $\beta$ can act as an angiostatic or angiogenic factor. Low doses of TGF- $\beta$ stimulate proliferation of endothelial cells and tube formation but TGF- $\beta$ becomes inhibitory at high concentrations. Additionally, TGF- $\beta$ reduces the degradation of the perivascular matrix by an induction of protease inhibitors and by reduction of proteases [50]. The higher concentration of TGF- $\beta$ inhibit the endothelial regeneration but it facilitates the recruitment of vascular smooth muscle cells (SMC) into the site of injury. Similarly, TGF- $\beta$ exerts a dose-dependent influence on SMC proliferation, being stimulatory at low concentration and inhibitory at high concentration [5]. Therefore, it maintains the normal vessel wall architecture and loss of this protective role results in the development of atherosclerosis [27].

\section{TGF- $\beta$ - CABG}

All models of vascular intervention, including bypass surgery or balloon angioplasty, cause mural injury. This can be explained by the epithelium uncover, disruption and death to underlying smooth muscle cells and initiation of an inflammatory reaction.

Denizot et al. found that TGF- $\beta$ plasma levels increase during the coronary artery bypass graft surgery and after removal of the aortic cross-clump and decrease thereafter. It suggests that heart can be a potential source of TGF- $\beta$ [16]. That is in accordance to physiological state when repair process of injured tissues is associated with increased expression of TGF- $\beta$ by macrophages and parenchymal cells [9]. However, considering the profibrotic nature of the cytokine it is not surprising that TGF- $\beta$ is also involved in postangioplasty restenosis, postinfarction myocardial remodeling resulting in the development of heart failure and other fibrosis-related cardiovascular diseases [15].

TGF- $\beta$ can promote the healing process of the injured myocytes since it exerts cardioprotection during acute myocardial ischemia. Attaran et al. have demonstrated that average circulatory TGF- $\beta 1$ concentrations in patients undergoing $\mathrm{CABG}$ are much lower when compared to those with normal coronary arteries [3]. The finding is with accordance to other clinical studies that demonstrated that patients with advanced atherosclerosis of coronary arteries present lower plasma levels of TGF- $\beta 1$ when compared to those without coronary artery disease (CAD) $[26,65]$. Therefore, the lower plasma level of TGF- $\beta$ can serve as a predictive factor in cardiovascular disease and mortality. 


\section{SUMMARY}

There have been many different families of angiogenic growth factors and their receptors discovered until now. On the basis of their biology it can be observed that different signaling systems, acting simultaneously and together or separately, are necessary for different stages of vessel growth. Particularly two all of growth factors - VEGF and FGF - play an important role in initiation of neovascularization process. The involvement of these molecules in angiogenesis is crucial for coronary artery disease revascularization, especially in patients with ungraftable arteries. Induction of new vessels formation can have influence on enhanced blood flow to ischemic areas of heart muscle. Thus, protein, gene or cellular therapy with use of angiogenic growth factors has emerged as a potential new treatment strategy for cardiovascular disease. Additionally, intramyocardial administration of angiogenic growth factors together with $\mathrm{CABG}$ can induce collateral development and improve myocardial perfusion. Therefore, it can be considered as an adjunct to surgical procedures. In conclusions, therapeutic angiogenesis seems to be the promising alternative for patients with advanced vascular disease not responding to conventional treatment.

\section{ACKNOWLEDGEMENT}

This work is supported by European Regional Development Fund and the Polish Government (Operational Programme Innovative Economy 2007 - 2013) under the grant „WROVASC - Integrated Cardiovascular Centre”.

\section{REFERENCES}

[1] ABRAMOV D, EREZ E, DAGAN O, ABRAMOV Y, PEARL E, VEENA G, KATZ J, VIDNE BA, BARAK V. Increased levels of basic fibroblast growth factors are found in the cross-clamped heart during cardiopulmonary bypass. Can J Cardiol 2000; 16:313-318

[2] ALVAREZ R, KANTARJIAN HM, CORTES JE. Biology of plateled-derived growth factoror and its. involvment in disease. Mayo Clin Proc 2006; 81:1241-1257

[3] ATTARAN S, SHERWOOD R, DASTIDAR MG, EL-GAMEL A. Identification of low circulatory transforming growth factor $\beta-1$ in patients with degenerative heart valce disease. Interact Cardiovasc Thorac Surg 2010; 11;791-793

[4] BATES DO, HILLMAN NJ, WILLIAMS BJ, NEAL CR, POCOCK TM. Regulation of microvascular permeability by vascular endothelial growth factors. Anat 2002; 200:581-597

[5] BATTEGAY EJ, RAINES EW, SEIFERT RA, BOWEN-POPE DF, ROSS R. TGF-beta induces bimodal proliferation of connective tissue cells via complex control pf an autocrine PDGF loop. Cell $1990 ; 63: 515-524$

[6] BATTEGAY EJ, RUPP J, IRUELA-ARISPE L, SAGE EH, PECH M. PDGF-BB modulates endothelial proliferation and angiogenesis in vitro via PDGF-beta recxeptors. J Cell Biol 1994; 125:917-928 
[7] BERNOTAT-DANIELOWSKI S, SHARMA HS, SCHOTT RJ, SCHAPER W. Generation and localization of monoclonal antibodies against fibroblast growth factors in ischaemic collateralized porcine myocardium. Cardiovasc Res 1993; 27:1220-1228

[8] BERSE B, BROWN LF, VAN DE WATER L, DVORAK HF, SENGER DR. Vascular permeability factor (vascular endothelial factor) gene is expressed differentially in normal tissues, macrophages, and tumors. Mol Biol Cell. 1992; 3:211-20

[9] BRANTON MH, KOPP JB. TGF- $\beta$ and fibrosis. Microbes Infect 1999; 1:1349-1365

[10] BURTON PBJ, OWEN VJ, HAFIZI S, BARTON PJR, CARR-WHITE G, KOH T, DE SOUZA A, YACOUB MH, PEPPER JR. Vascular endothelial growth factor release following coronary artery bypass surgery: extracorporeal circulation versus beating heart surgery. Eur Heart $\mathrm{J} 2000 ; 21: 1708$ 1713

[11] CASSCELLS W, SPEIR E, SASSE J, KLAGSBRUN M, ALLEN P, LEE M, CALVO B, CHIBA M, HAGGROTH L, FOLKMAN J, et al. Isolation, characterization, and localization of heparin-binding growth factors in the heart. J Clin Invest 1990; 85:433-441

[12] CLAFFEY KP, ABRAMS KRISTIN, SHIH SC, BROWN LF, MULLEN A, KEOUGH M. Fibroblast growth factor 2 activation of stromal cell vascular endothelial growth factor expression and angiogenesis. Lab Invest 2001; 81:61-75

[13] CLAUSS M, GERLACH M, GERLACH H, BRETT J, WANG F, FAMILLETTI PC, PAN Y-C, OLANDER JV, CONNOLLY DT, STERN D. Vascular permeability factor: a tumor-derived polypeptide that induces endothelial cell and monocyte procoagulant activity, and promotes monocyte migration. J Exp Med 1990; 172:1535-1545

[14] DAVIS S, ALDRICH TH, JONES PF, ACHESON A, COMPTON DL, JAIN V, RYAN TE, BRUNO J, RADZIEJEWSKI C, MAISONPIERRE PC, YANCOPOULOS GD. Isolation of angiopoietin-1, a ligand for the TIE2 receptor, by secretion-trap expression cloning. Cell 1996; 87: 1161-1169

[15] DĄBEK J, KUŁACH A, MONASTYRSKA-CUP B, GĄSIOR Z. Transforming growth factor $\beta$ and cardiovascular diseases: the other facet of the ,protective cytokine“. Pharmacol Rep 2006; 58:799-805

[16] DENIZOT Y, GUGLIELMI L, CORNU E, NATHAN N. Alterations in plasma angiogennic growth. factor concentrations after coronary artery bypass. graft surgery: relationships. with post-operative. complications. Cytokine 2003; 24:7-12

[17] DIMMELER S, DERNBACH E, ZEIHER AM. Phosphorylation of the endothelial nitric oxide synthase at ser-1177 is required for VEGF-induced endothelial cell migration. FEBS Lett 2000; 477:258-262

[18] DVORAK HF. Vasscular permeability factor/vascular endothelial growth factor:- a critical cytokine in tumor angiogenesis and a potential target for diagnosis and therapy. J Clin Oncol 2002;20:4368-4380

[19] FARNEBO F, PIEHL F, LAGERCRANTZ J. Restricted expression pattern of vegf-d in the adult and fetal mouse: high expression in the embryonic lung. Biochem Biophys Res Commun 1999; 257:891894

[20] FIEDLER U, SCHARPFENECKER M, KOIDL S, HEGEN A, GRUNOW V, SCHMIDT JM, KRIZ W, THURSTON G, AUGUSTIN HG. The Tie-2 ligand angiopoietin-2 is stored in and rapidly released upon stimulation from endothelial cell Weibel-Palade bodies. Blood 2004; 103:4150-4256

[21] FRIEDL R, LI J, SCHUMACHER B, HANKE H, WALTENBERGER J, HANNEKUM A, STRACKE S. Intimal hyperplasia and expression of transforming growth factor- $\beta 1$ in saphenous veins and internal mammary arteries before coronary artery surgery. Ann Thorac Surg 2004; 78:1312-1318

[22] FRAZIER AA, QURESHI F, READ KM, GILKESON RC, POSTON RS, WHITE CS. Corononary. artery bypass grafts: assessment with multidetector. CT in the early and late postoperative settings. Radiographics. 2005; 25:881-896

[23] FUJITA M, IKEMOTO M, KISHISHITA M, OTANI H, NOHARA R, TANAKA T, TAMAKI S, YAMAZATO A, SASAYAMA S. Elevated basic fibroblast growth factoror in pericardial fluid of patients with unstable angina. Circulation 1996; 94:610-613

[24] GALE NW, THURSTON G, HACKETT SF, RENARD R, WANG Q, MCCLAIN J, MARTIN C, WITTE C, WITTE MH, JACKSON D, SURI C, CAMPOCHIARO PA, WIEGAND SJ, YANCOPOULOS GD. Angiopoietin-2 is required for postnatal angiogenesis and lymphatic patterning, and only the latter role is rescued by Angiopoietin-1. Dev Cell 2002; 3:411-423

[25] GHOSH J, MURPHY MO, TURNER N, KHWAJA N, HALKA A, KIELTY CM, WALKER MG. The role of transforming growth factor $\beta 1$ in the vascular system. Cardiovasc Pathol 2005; 14:28-36 
[26] GRAINGER DJ, KEMP PR, METCALFE JC, LIU AC, LAWN RM, WILLIAMS NR, GRACE AA, SCHOFIELD PM, CHAUHAN A. The serum concentration of active transforming growth factor-beta is severely depressed in advanced atherosclerosis. Nat Med 1995; 1:74-79

[27] GRAINGER DJ. Transforming growth factor $\beta$ and atherosclerosis: So far, so good for the protective cytokine hypothesis. Arterioscler Thromb Vasc Biol 2004; 24:399-404

[28] HASDAI D, BARAK V, LEIBOVITZ E, HERZ I, SCLAROVSKY S, ELDAR M, SCHEINOWITZ M. Serum basic fibroblast growth factor levels in patients with ischemic heart disease. Int $\mathrm{J}$ Cardiol $1997 ; 59: 133-138$

[29] HELDIN CH. Structural and functional studies on platelet-derived growth factor. EMBO J 1992; 11:4251-4259

[30] HELDIN CH, WESTERMARK B. Mechanism of action and in vivo role of plateled-derived growth factor. Physiol Rev 1999; 79:1283-1316

[31] HOLASH H, MAISONPIERRE PC, COMPTON D, BOLAND P, ALEXANDER CR, ZAGZAG D, YANCOPOULOS GD, WIEGAND SJ. Vessel cooption, regression, and growth in tumors mediated by angiopoietins and VEGF. Science 1999; 284:1994-1998

[32] HOLMES K, ROBERTS OLL, ANGHARAD MT, CROSS MJ. Vascular endothelial growth factor-2: Structure, function, intracellular signalling and therapeutic inhibition. Cellular Signalling 2007; 19:2003-2012

[33] HUWER H, WELTER C, ÖZBEK C, SEIFERT M, STRAUB U, GREILACH P, KALWEIT G, ISRINGHAUS H. Simultaneous surgical revascularization and angiogenic gene therapy indiffuse coronary artery disease. Eur J Cardiothorac Surg. 2001; 20:1128-1134

[34] JONES EL, CRAVER JM, GUYTON RA, BONE DK, HATCHER CR JR, RIECHWALD N Importance of complete revascularization in performance of the coronary bypass operation. Am $\mathrm{J}$ Cardiol 1983; 51:7-12

[35] KOHN S, NAGY JA, DVORAK HF, DVORAK AM. Pathways of macromolecular tracer transport across venules and small veins. Structural basis for the hyperpermeability of tumor blood vessels. Lab Invest 1992; 67:596-607

[36] KOYAMA H, NISHIZAWA Y, HOSOI M, FUKUMOTO S, KOGAWA K, SHIOI A, MORII H. The fumagillin analogue TNP-470 inhibits DNA synthesis of vascular smooth muscle cells stimulated by platelet-derived growth factor and insulin-like growth factor-I. Possible involvement of cyclindependent kinase 2. Circ Res. 1996; 79:757-764

[37] KUKK E, LYMBOUSSAKI A, TAIRA S, KAIPAINEN A, JELTSCH M, JOUKOV V, ALITALO K. VEGF-C receptor binding and pattern of expression with VEGFR-3 suggests a role on lymphatic vascular development. Development 1996; 122:3829-3837

[38] LAHAM RJ, SELLKE FW, EDELMAN AR, PEARLMAN J, WARE A, BROWN DL, GOLD JP, SIMONS M. Local perivascular delivery of basic fibroblast growth factor in patients undergoing coronary bypass surgery: results of a phase I randomized, double-blind, placebobo-controlled trial. Circulation 1999; 100:1865-1871

[39] LAROCHELLE WJ, JEFFERS M, MCDONALD WF, CHILLAKURU RA, GIESE NA, LOKKER NA, SULLIVAN C, BOLDOG FL, YANG M, VERNET C, BURGESS CE, FERNANDES E, DEEGLER LL, RITTMAN B, SHIMKETS J, SHIMKETS RA, ROTHBERG JM, LICHENSTEIN HS. PDGF-D, a new protease-activated growth factor. Nat Cell Biol. 2001; 3:517-521

[40] LEVIN DC, BECKMANN CF, SOS TA, SNIDERMAN K. Incomplete myocardial reperfusion despite a patent coronary bypass: a generally unrecognized shortcoming of the surgical approach to coronary artery disease. Radiology. 1982; 142:317-321

[41] LI X, PONTEN A, AASE K, KARLSSON L, ABRAMSSON A, UUTELA M, BÄCKSTRÖM G, HELLSTRÖM M, BOSTRÖM H, LI H, SORIANO P, BETSHOLTZ C, HELDIN CH, ALITALO K, OSTMAN A, ERIKSSON U. PDGF-C is a new protease-activated ligand for the PDGF alphareceptor. Nat Cell Biol. 2000; 2:302-309

[42] LINDAHL P, JOHANSSON BR, LEVEEN P, BETSHOLTZ C. Pericyte loss and microaneurysm formation in PDGF-B-deficient mice. Science 1997; 277:242-245

[43] LOBOV IB, BROOKS PC, LANG RA. Angiopoietin-2 displays VEGF-dependent modulation of capillary structure and endothelial cell survival in vivo. Proc Natl Acad Sci USA 2002; 99:1120511210 
[44] LYTTLE DJ, FRASER KM, FLEMING SB, MERCER AA, ROBINSON AJ. Homologs of vascular endothelial growth factor are encoded by the poxvirus orf virus. J Virol 1994; 68:84-92

[45] MELDER RJ, KOENIG GC, WITWER BP, SAFABAKHSH N, MUNN LL, JAIN RK. During. angiogenesis, vascular endothelial growrh factor and basic fibroblast growth factor regulate natural killer cell adhesion to tumor endothelium. Nature Med 1996; 2:992-997

[46] METAIS C, LI J, LI J, SIMONS M, SELLKE FW. Effects of coronary artery disease on expression and microvascular response to VEGF. Am J Physiol Heart Circ Physiol 1998; 275:1411-1418

[47] MUKHERJEE D, BHATT DL, ROE MT, PATEL V, ELLIS SG. Direct myocardial revascularization and angiogenesis - how many patients might be eligible? Am J Cardiol 1999; 84:598-600

[48] OLOFSSON B, PAJUSOLA K, KAIPAINEN A, VON EULER G, LOUKOV V, SAKSELA O, ORPANA A, PETTERSSON RF, ALITALO K, ERIKSSON U. Vascular endothelial growth factor B, a novel growth factor for endothelial cells. Proc Natl Acad 1996; 93:2576-2581

[49] PEPPER MS, FERRARA N, ORCI L, MONTESANO R. Vascular endothelial growth factor (VEGF) induces plasminogen activators and plasminogen activator inhibitor-1 in microvascular endothelial cells. Biochem Biophys Res Commun 1991; 181:902-906

[50] PEPPER MS. Transforming growth factor- $\beta$ : vasculogenesis, angiogenesis, and vessel wall integrity. Cytokine Growth Factor Rev 1997; 8:21-43

[51] PERTOVAARA L, KAIPAINEN A, MUSTONEN T, ORPANA A, FERRARA N, SAKSELA O, ALITALO K. Vascular endothelial growth factor is induced in response to transforming growth factorbeta in fibroblastic and epithelial cells. J Biol Chem. 1994; 269:6271-6274

[52] PICHIULE P, CHAVEZ JC, LAMANNA JC. Hypoxic regulation of angiopoietin-2 expression in endothelial cels. J Biol Chem 2004; 279:12171-12180

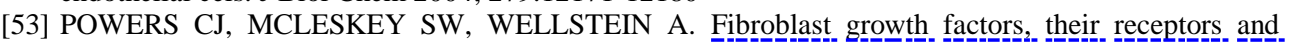
signaling. Endocr Relat Cancer 2000; 7:165-197

[54] ROSENGART TK, LEE LY, PATEL SR, et al. Six-month assessment of a phase I trial of angiogenic gene therapy for the treatment of coronary artery disease using direct intramyocardial administration of an adenovirus vector expressing the VEGF121 cDNA. Ann Surg 1999; 230: 466-470

[55] ROSS R. The pathogenesis of atherosclerosis: a perspective for the 1990s. Nature 1993; 362:801-809

[56] RUTHERFORD C, MARTIN W, CARRIER M, ANGGARD EE, FERNS GA. Endogenously elicited antibodies to platelet derived growth factor-BB and platelet cytosolic protein inhibit aortic lesion development in the cholesterol-fed rabbit. Int J Exp Pathol 1997; 78:21-32

[57] RUTHERFORD C, MARTIN W, SALAME M, CARRIER M, ANGGARD E, FERNS G. Substantial inhibition of neo-intimal response to balloon injury in the rat carotid artery using a combination of antibodies to platelet-derived growth factor-BB and basic fibroblast growth factor. Atherosclerosis 1997; 130:45-51

[58] SCHNEIDER H, HUSE K. Arterial gene therapy. Lancet 1996; 348:1380-1382

[59] SCHUMACHER B, PECHER P, VON SPECHT BU, STEGMANN T. Induction of neoangiogenesis in ischemic myocardium by human growth factors: first clinical results of a new treatment of coronary heart disease. Circulation 1998; 97:645-650

[60] SEGHEZZI G, PATEL S, REN CJ, GUALANDRIS A, PINTUCCI G, ROBBINS ES, SHAPIRO RL, GALLOWAY AC, RIFKIN DB, MIGNATTI P. Fibroblast growth factor-2 (FGF-2) induces vascular endothelial growth factor (VEGF) expression in the endothelial cells of forming capillaries: an autocrine mechanism contributing to angiogenesis. J Cell Biol 1998; 141:1659-1673

[61] SELLKE FW, RUEL M. Vascular growth factors and angiogenesis in cardiac surgery. Ann Thorac Surg 2003; 75:685-690

[62] SHWEIKI D, ITIN A, SOFFER D, KESHET E. Vascular endothelial growth factor induced by hypoxia may mediate hypoxia-initiated angiogenesis. Nature 1992; 359:843-845

[63] SLAVIN J. Fibroblast growth factors: at the heart of angiogenesis. Cell Biol Int 1995; 19:431-444

[64] SPORN MB, ROBERTS AB, WAKEFIELD LM, DE CROMBRUGGHE B. Some recent advances in the chemistry and biology of transforming growth factor-beta. J Cell Biol. 1987; 105:1039-1045

[65] TASHIRO H, SHIMOKAWA H, YAMANOTO K, MOMOHARA M, TADA H, TAKESHITA A. Altered plasma levels of cytokines in patients with ischemic heart disease. Coron Artery Dis 1997; 8:143-147

[66] THURSTON G. Role of Angiopoietins and Tie receptor tyrosine kinases in angiogenesis and lymphangiogenesis. Cell Tissue Res 2003; 314:61-68 
[67] VALENZUELA DM, GRIFFITHS JA, ROJAS J, ALDRICH TH, JONES PF, ZHOU H, MCCLAIN J, COPELAND NG, GILBERT DJ, JENKINS NA, HUANG T, PAPADOPOULOS N, MAISONPIERRE PC, DAVIS S, YANCOPOULOS GD. Angiopoietins 3 and 4: diverging gene counterparts in mice and humans. Proc Natl Acad Sci USA 1999; 96:1904-1909

[68] VEIKKOLA T, KARKKAINEN M, CLAESSON-WELSH L, ALITALO K. Regulation of angiogenesis via vascular endothelial growth factor receptors. Cancer Res 2000; 60:203-212

[69] WILSON JM, FERGUSON JJ. Revascularization therapy for coronary artery disease. Coronary artery bypass grafting versus percutaneous transluminal coronary angioplasty. Tex Heart Inst J. 1995; 22:145-161

[70] YAMAZAKI Y, TAKANI K, ATODA H, MORITA T. Snake venom vascular endothelail growth factors (VEGFs) exhibit potent activity through their specific recognition of KDR (VEGF receptor 2). J Biol Chem 2003; 278:51985-51988

[71] YAMAZAKI Y, MORITA T. Molecular and functional diversity of vascular endothelial growth factors. Divers 2006; 10:515-527

[72] YANCOPOULOS GD, DAVIS S, GALE NW, RUDGE JS, WIEGAND SJ, HOLASH J. Vascularspecific growth factors and blood vessel formation. Nature 2000; 407: 242-248

[73] ZACHARY I, GLIKI G. Signaling transduction mechanisms mediating biological actions of the vascular endothelial growth factor family. Cardiovasc Res 2001; 49:568-581

Corresponding author: Karolina Sterzynska

Department of Histology and Embryology

Poznan University of Medical Sciences

Swiecicki Str. 6

60-781 Poznan, Poland

phone +48618546428

fax. +48618546440

e-mail:k.olejniczak@ump.edu.pl 